\title{
The Importance of the Philosophy in our Days
}

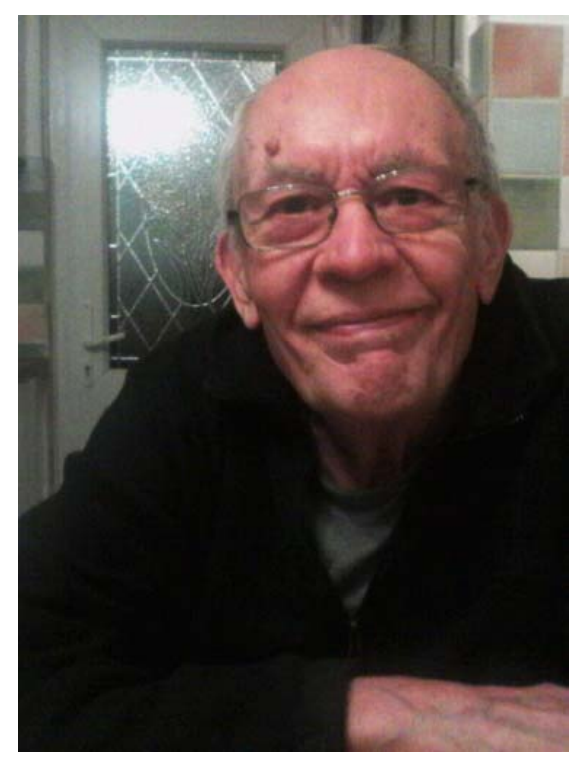

Michael Inwood was born in London in 1944. From 1967 until 2011 he was a Fellow and Tutor in Philosophy at Trinity College, Oxford. He is now an Emeritus Fellow of the College and lives in Oxford. He has produced various publications on Heidegger, Hegel, and ancient philosophy.

Tudor Petcu: Although, the philosophy has a lot of meanings and definitions, I wonder which would be the best definition of philosophy. So, at the beginning of our dialogue I would like to ask you how would you define philosophy?

Michael Inwood: As you say, the word 'philosophy' has a wide variety of meanings or uses, covering, for example, the precepts or beliefs underlying a person's approach to life (as in 'My philosophy is ...'), calm resignation (as in 'approaching disasters philosophically'), and the systematic examination of our fundamental concepts, such as truth, causality, and freedom. Since I have spent most of my life teaching philosophy as an academic discipline, the last of these meanings comes closest to what I engaged in. However, even that fairly restricted account of philosophy might be applied to a wide variety of enterprises. The work of two people who are customarily regarded as philosophers, say, Nietzsche and Frege, might seem to have relatively little in common. The concept of philosophy is perhaps what is sometimes called an 'essentially contested concept', along with such concepts as art, religion, poetry, democracy, and freedom, where there is wide divergence both in the definition of the concept and in the application of it. I might respond to your question by asking why you ask it? After all, if I were a mathematician, a chemist or a physicist, you would not begin by asking me to define chemistry, etc. A chemist can quite happily pursue his or her subject without worrying about how to define it. Perhaps the answer is that philosophy is intrinsically a reflective or meta-discipline, in a way that, say, chemistry is not. From the very beginning, philosophers such as Socrates and Plato, have never been content simply to practice philosophy, but have always felt bound to ask 'What is philosophy?' and 'What is the point of doing it?' 
Tudor Petcu: We are usually talking in our days about the so called "pragmatic world". What do you exactly understand by "the pragmatic world"? Which are in your opinion the main reasons that made possible this pragmatism in the world that I'm trying to talk about?

Michael Inwood: 'Pragmatic world' is not a usual English expression and I am not quite sure what you mean by it. If you mean the 'practical world,' in the sense of the world in which we are concerned with practical results, rather than theories and principles, then there has always been a pragmatic world in that sense and even philosophers and scholars in other disciplines spend a great deal of their time in it. If I have a toothache, I consult a dentist rather than a philosopher. Socrates himself worked as a stone mason and also reflected on the nature of a craft. Many British and American philosophers have thought it fruitful and important to reflect on common practical life and language rather than to confine their attention to technical philosophical matters, even if they do not go as far as becoming stone masons. On the other hand, there has been a tendency among philosophers to think that a life of philosophical contemplation is, if not the only good life, at least the best sort of life. Socrates goes even further in saying that the unexamined life is not worth living. I cannot see much reason to accept this extravagant claim. I am reminded of Lord Macaulay's response to Seneca, who expressed contempt for practical inventions and their inventors, saying 'We shall next be told that the first shoemaker was a philosopher!' Macaulay commented: 'For our own part, if we are forced to make a choice between the first shoemaker and the author of the three books On Anger, we pronounce for the shoemaker. It may be worse to be angry than to be wet. But shoes have kept millions from being wet; and we doubt whether Seneca ever kept anybody from being angry.'

On the other hand, the 'pragmatic world' may be the specifically modern world that Max Weber had in mind when he said: "The fate of our times is characterized by rationalization and intellectualization and, above all, by the "disenchantment of the world". 'Rationalization' involves cost-benefit calculation and bureaucratic organization, while 'disenchantment' involves desacralization or secularization, the decay of traditional institutions and beliefs expressing the spiritual dimension. The church is replaced by the supermarket, priests by medical doctors, and so on. Socrates himself made a contribution to all this by insisting that we must have good, explicit reasons for everything we do and believe. Weber assigned an important role to ascetic Protestantism, especially Calvinism, with its stress on one's secular vocation as service to God. More generally, the Enlightenment laid the groundwork for such a society, with its critique of religion and of tradition and its ideal of rationality, though the Enlightenment itself presumably owes something to the Protestant reaction against Catholicism. Religion played a big part in its own decline.

Tudor Petcu: Can we say that postmodernism is a reason which encourages the development of the pragmatism? Do you think that postmodernism represents a paradigm that "betrays" contemplative thinking?

Michael Inwood: I find the term 'postmodernism' too vague and amorphous to able to answer this question definitively. I have found one example of its use in 1914: 'The raison-d'etre of PostModernism is to escape from the double-mindedness of Modernism by being thorough in its criticism - by extending it to religion as well as theology, to Catholic feeling as well as to Catholic tradition.' In this sense, post-modernism would contribute to the disenchantment and rationalism that I mentioned above. However, in the sense in which word is now used, at least to refer to a philosophical movement, it suggests an attempt to undermine Enlightenment beliefs and values, such as objective truth, historical progress, univocity of meaning, and the certainty of universal rational explanations, and to reject ideology and theory in favour a plurality of beliefs and values. It 
is perhaps reminiscent of the 18th century romantic reaction against Enlightenment. Postmodernism in this sense might well encourage a version of pragmatism in deciding what to believe and how to act: if there are no objective truths or values, why should I not do and believe what it suits my purposes to do or believe? However, I do not see why postmodernism as I have outlined it should 'betray' contemplative thinking - except if, as it sometimes does, it falls below acceptable standards of coherence and intelligibility.

Tudor Petcu: From a certain point of view, maybe we can say that the 20th century meant a tendency to eliminate metaphysics. For instance, we can remember Rudolf Carnap who has been writing about the elimination of metaphysics through the logical analysis of the language. But in spite of this fact that I have emphasized, could we find a certain method of the truth in metaphysics?

Michael Inwood: Philosophers have often felt the need to distinguish their own way of doing philosophy from various spurious versions of the discipline. For Socrates and Plato, the enemy was sophistry. For medieval philosophers it was heresy and atheism. In early modern times the target of ridicule was scholasticism, as well as atheism. And, as you say, in the 20th century it was metaphysics. The word 'metaphysics' does not, however, have a single, clear meaning. It surely belongs alongside those essentially contested concepts that I mentioned earlier. For medieval philosophers it meant something like 'ontology,' the study of being and the most general characteristics of beings. For Carnap and the logical positivists it meant claims that were unverifiable, that breached the so-called 'verification principle' and that were therefore 'meaningless.' It was intended especially to include religious claims, but also linguistically deviant claims, such as Heidegger's 'Das Nichts selbst nichtet' ('The nothing noths/nihilates'), and similar claims made by the likes of Hegel. Heidegger himself favoured metaphysics until at least the mid1930s, regarding it as more or less equivalent to 'ontology.' But in later writings he came to regard it as baneful, especially in the form of 'ontotheology,' and as responsible for our misguided technological view of the world. However, in the latter part of the century, Anglo-Saxon philosophers, especially Kant specialists, such as W. H. Walsh and Sir Peter Strawson, began to adopt a more generous attitude towards metaphysics. Strawson regarded himself as a 'descriptive metaphysician,' in the sense of examining our most fundamental concepts. Unlike Carnap and Ayer, he believed that the claims of such paradigmatic metaphysicians as Hegel were meaningful, even if their meaning was difficult to fathom. Several recent books have taken metaphysics seriously. I might mention Metaphysical Themes: 1274-1671, by Robert Pasnau, who explores medieval metaphysics in all its rich diversity and subtlety. Another is Adrian Moore's book, The Evolution of Modern Metaphysics: Making Sense of Things. Defining 'metaphysics' as 'the most general attempt to make sense of things,' Moore embraces a wide range of philosophers under this heading, even philosophers, such as Carnap, Frege and Quine, who would not have regarded themselves as metaphysicians. It is, in my view, a serious defect in Moore's survey that he excludes scientists such as Newton and Einstein, who surely have a better claim to have made sense of things than, say, Frege. But on the whole the catholicity of Moore's tastes, and the sympathetic insight with which he treats all his metaphysicians, are exemplary. It remains the case, however, that 'transcendent' metaphysics, which includes most religious metaphysics, is still suspect in the eyes of most AngloSaxon philosophers.

Tudor Petcu: Which would be from your point of view the best philosophical direction that could be assumed so that we can better understand "the pragmatic world"?

Michael Inwood: Again, it depends on what you mean by the 'pragmatic world' and also by 'understand.' If by the 'pragmatic world' you have in mind the world of political intrigue and economic competition, and if by 'understanding' you mean the shrewdness and experience to survive in this difficult and dangerous environment, then philosophy is of little use. Philosophy may 
teach us wisdom, but it does not teach us streetwisdom - a word that does not appear in English dictionaries, but seems a natural extension of the adjective 'streetwise,' i.e. having the skills and knowledge to cope with modern urban life. Plato himself, perhaps the greatest of philosophers, came to grief in the politics of Syracuse, and Heidegger, though a great philosopher, became entangled in the toils of Nazism. If, on the other hand, by 'understanding' you mean reflective understanding, then I do not see why a philosopher should not understand the pragmatic world in this sense. It was, for example, a philosopher, Adam Smith, who developed a good understanding, still widely respected, of the economic system, of the motivations and machinations of businessmen, and so on. But such reflective understanding requires one to step back, distance oneself, from the practical activity that one is considering. I do not know whether Smith was himself an astute businessman. But even if he was, he was not acting as a businessman when he reflected upon their activities. This is true of the understanding of practical activity generally, I think. One cannot, while one is changing a light-bulb, engage in reflection on the phenomenology of changing a light-bulb. One has to think about that afterwards. Reflection on practical activity is a theoretical activity, not a practical activity.

It seems to me that one difficulty that philosophers might have in understanding political affairs is their tendency to focus on the truth of statements and the validity of arguments. For example, it is widely claimed by British politicians that if a person smokes and, as a result, becomes ill and dies sooner than non-smokers, then this imposes a financial burden on the health service and thereby on the public purse. This is obviously untrue, because even non-smokers get ill eventually and, if they live longer, they require a pension and other support paid for by others. However, to criticise the claim on this ground is not sufficient. Some politicians may not recognise its falsity, but others surely do. Then to understand what they say requires us to understand why they are saying it. The truth of a proposition is neither a necessary nor a sufficient reason for asserting it. Politicians are, in my view, often far more intelligent than they appear to be in public. To underrate them is to underrate the difficulty of governing a complex society.

Tudor Petcu: Usually, it's much easier to take into account the differences between the philosophical thinking and the pragmatic thinking. But if we would make an effort to find a common denominator between these two types of thinking would we have any chance to find it? If so, which would be from your perspective this common denominator?

Michael Inwood: I said earlier that reflection on practical activity is not itself a practical activity. But now I need to qualify this. The ideal of theoretical contemplation is, no doubt, not practical in the least. But a contemporary academic philosopher does not usually aspire to such an ideal. He or she is competing in an academic market-place in much the same way as Adam Smith's businessman. Young philosophers need to publish in order to get a much-coveted and hotly contested university post. And later they need to publish in order to gain tenure, promotion, grants, and prestige among their peers. They have to find an area, preferably a fashionable area, towards which to direct their thinking and in which they have something original and plausible to say. A philosopher who simply agrees with everything said by another philosopher and has nothing to add will gain no credit for this, except perhaps from that other philosopher. He or she must say something different from other philosophers and perhaps criticise other philosophers even if they privately agree with them. Philosophers are in this respect somewhat like politicians who must often support publicly policies that they do not agree with. There are differences, of course. Politicians need to support their party; a philosopher may need to do this in order to secure promotion, but he or she may gain credit for their independence. Again, the philosopher's audience is usually, though not invariably, more astute and critical than that of a politician, so that philosophers must pay more attention to the truth, or at least the verisimilitude, of their statements and to the validity of their arguments. The moral of this is that not only should we not believe everything that philosophers 
say, but we should not believe that they believe it themselves. You might think that this applies to myself, of course. But since I have retired from the profession and withdrawn from the academic market-place, I have no reason to deceive anyone, apart from intellectual incompetence. 